\title{
Influence of Strategic Interrelationships and Decision-Making in Chilean Port Networks on Their Degree of Sustainability
}

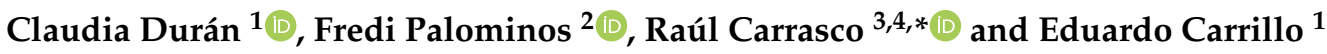 \\ 1 Departamento de Ingeniería Industrial, Universidad Tecnologica Metropolitana, Santiago 7800002, Chile; \\ c.durans@utem.cl (C.D.); eduardo.carrillol@utem.cl (E.C.) \\ 2 Departamento de Matemática y Ciencia de la Computación, Facultad de Ciencia, \\ Universidad de Santiago de Chile, Santiago 9170124, Chile; fredi.palominos@usach.cl \\ 3 Facultad de Ingeniería, Ciencia y Tecnología, Universidad Bernardo O’Higgins, Santiago 8370993, Chile \\ 4 Facultad de Ingeniería, Universidad Andres Bello, Santiago 7500971, Chile \\ * Correspondence: raul.carrasco.a@usach.cl
}

\section{check for}

updates

Citation: Durán, C.; Palominos, F.; Carrasco, R.; Carrillo, E. Influence of Strategic Interrelationships and Decision-Making in Chilean Port Networks on Their Degree of Sustainability. Sustainability 2021, 13, 3959. http://doi.org/10.3390 /su13073959

Academic Editors: Juan-José

Alfaro-Saiz and Raúl

Rodríguez-Rodríguez

Received: 12 February 2021

Accepted: 31 March 2021

Published: 2 April 2021

Publisher's Note: MDPI stays neutral with regard to jurisdictional claims in published maps and institutional affiliations.

Copyright: (C) 2021 by the authors. Licensee MDPI, Basel, Switzerland. This article is an open access article distributed under the terms and conditions of the Creative Commons Attribution (CC BY) license (https:/ / creativecommons.org/licenses/by/ $4.0 /)$.

\begin{abstract}
An extensive literary review is carried out to determine the strategic and business advantages, and difficulties that non-smart ports must face to develop sustainability. Based on a two-port case study, the strategic text of the corporate missions of port administrators and operators is analyzed and classified in order to understand to what extend economic, social and environmental aspects are fulfilled. A conceptual model is designed for an information system based on indicators that can determine the state or degree of sustainability in the critical operational activities of the ports studied. A system is proposed that is based on a data warehouse core and a multidimensional database, which can be implemented in the Relational On-Line Analytical Processing (ROLAP) mode, allowing taking advantage of the good characteristics of relational databases without losing the On-Line Analytical Processing (OLAP) approach. A discussion of the strategic feasibility of implementing this conceptual model of case study monitoring and its long-term benefits is delivered. The conclusions state that the development of this green technology requires cultural changes, public policy initiatives and the incorporation of new actors. In addition, more research is needed in this area to identify other relevant sustainable variables.
\end{abstract}

Keywords: decision making; multidimensional databases; OLAP; port system; sustainability

\section{Introduction}

Sustainability is identified as a key factor that improves competitiveness and minimizes risks, in which long-term investment results are obtained [1]. Port sustainability is understood as the state reached by a company or a port community as a whole, in which said industry meets a set of requirements, covering three important areas such as economic, social and environmental aspects. It implies the incorporation of strategies, business models and operational aspects related to: the profitability of export and import logistics activities, governance, legitimacy in the eyes of the communities interacting with the port, the creation of fair jobs and ethics, the development of knowledge and education, customer loyalty, ecological and environmental pressure due to pollution, etc. [2-4].

The main sustainable certification initiative is EcoPorts of the European Union, with the objective of improving environmental management through collaboration and exchange of knowledge between ports that are already certified, and the continuous improvement of logistics processes [5].

\subsection{Sustainability in Maritime Ports}

For the port industry to incorporate sustainability as part of its objectives and strategic actions in social, environmental and economic aspects, first it must facilitate collaboration and possible alliances between the actors that build the port network. This network is 
composed by the companies that provide logistics services, workers' unions, the inhabitants and authorities of the city occupied by the port and the government [6,7]. It is important for ports to effectively integrate sustainability in order to have less complex and stressful links between the managing company with its terminals and the city, to build trust between them and to integrate them as part of the urban system [8]. On the other hand, there are cases in developed countries in which green or ecological environmental policies have been proposed which complement port strategies, such as the cases of the ports of Vancouver, Los Angeles and Rotterdam [9].

Incorporating sustainable policies as part of the port business is important, since with them it is possible to optimally comply with strategic planning and improve important aspects of the port industry such as those related to: stakeholder management, risk management, profitability in investment projects, efficiency in the use of the facilities, management of traffic congestion in the land transport network, greenhouse gas emissions from maritime transport, climate changes, oil spills, deterioration of air, water and soil quality, noise pollution, use of clean energy, social protests, logistical problems of supplying markets, union strikes, job creation, habitability of areas near the port, the relations between the port and the city it occupies, among others [9-13].

The implementation of sustainable actions generates competitive advantages for a maritime port, since they improve the quality of the provision of services and differentiates the port from the competition due to the provision of more efficient and effective support to its internal and external clients[14]. Another important benefit to mention for a publicly owned port is that the interventions made by the State, such as audits for environmental problems, are reduced [15]. It must be considered that it is difficult to balance the three aspects of sustainability, since having an ecological port requires a cultural change in all the actors that build the port network and provide large investments, which may not be reflected in short-term profitability [16].

Finally, there is evidence [17] that affirms that sustainability is a good practice for both management and evaluation and that it contributes to efficient and effective decisionmaking, which is being increasingly required by port authorities. To implement sustainability it is necessary to comply with environmental regulations and use indicators that measure energy and water consumption, air and water quality, environmental fines, investments and costs involved in the environmental area, $\mathrm{CO}_{2}$ emissions, quality of life of the inhabitants, among other factors [18,19]. For effective management control, it is convenient to implement an environmental monitoring system that contains a set of indicators able to represent the situation of the port, and that objectively measure the performance of the activities considered relevant for the execution of the logistics processes [20].

\subsection{Monitoring Technologies}

It is difficult to establish sustainability evaluation criteria since there are multiple macro and microenvironment factors that affect it; despite this complexity, quantitative indicators have been developed to evaluate their performance [21]. It should be noted that there are few research cases that analyze new dimensions of sustainability or that study quantitative systems. This lack of variables affects the quality of the information that decision makers receive [22].

On the other hand, the adoption of technologies is an important tool to extract information and knowledge through the monitoring of port logistics processes [23]. The constant follow-up and monitoring of the indicators that reflect the "health status" of the sustainability of a company or production system, requires not only the implementation of operating procedures or protocols, but also the collection of timely, coherent and reliable information on the state and evolution of the production processes [24,25]. For several decades, computing has provided the tools and support necessary to store and manage data to such an extent that the amount of information available has itself become another problem [26]. Given that sustainability assessment represents a multidimensional problem, it is necessary to provide tools that allow exploring this multidimensionality, for which 
analytical approaches such as On-Line Analytical Processing (OLAP) are very useful in circumstances such as those described in this paragraph [27].

More and more automation and integration of data sources are required, which support decision-making in green or smart ports [28]. The intelligent use of data can generate a different business logic with novel economic models to improve planning and control of productivity management [29].

\subsection{OLAP and the Multidimensional Database}

OLAP is an information modeling and organizational approach that emphasizes the accessibility and ease of data processing, optimizes storage efficiency, the level of details of transactions and the degree of standardization of stored data [30]. The central idea comes from the 1960s, as a response to the need to perform analytical operations on the information stored in the operational information systems, which were limited due to multiple conditions that did not allow the managers of the organizations to access information when making decisions, in a timely and reliable manner [31]. OLAP provided the ability to dynamically perform multidimensional analyses, freeing end users from a relevant part of the complexity of making inquiries about computer systems, allowing them to perform analytical and navigational activities, such as manipulation and transformation of dimensions, analysis by periods of time; and providing them the ability to visualize subsets of data, move between different levels of aggregation, as well as comparing dimensions in a specific visualization area [32].

In OLAP, dimensions can be interpreted as points of view on problems or situations where manipulation and analysis of sets of indicators is required. Each dimension also provides a set of characteristics that allow the data to be classified, which added to the rest of the dimensions constitute a coordinate system where the values of the indicators (measurements) are functionally dependent on the values of the characteristics of such dimensions. Thus, a system based on an Online Analytical Processing approach will contain historical, summarized, and consolidated data obtained from the company's operational systems or from external sources. It will then be necessary to load and transfer data from administrative information systems or external data sources to a special database (multidimensional database) with added and refined information, which will facilitate the analysis of the changing values that the indicators may present at that time or at specific moments [33].

OLAP complements its semantic, organizational and structural approach with a basic set of functionalities materialized in a set of fundamental operators called: Pivot, Roll-up, Drill-down and Slice-Dicing, which are in practice the operational tools to perform not only the calculation and dimensions but also the analytical and navigational activities [32,34].

In relation to multidimensional databases, these were born as a technological response to implementing the OLAP approach [35]. Therefore, a Multidimensional Database (MDB) is a set of data whose organization and storage method responds to or are inspired by the OLAP approach. Since it is somewhat a technological approach more recent than that of other consolidated database models, the idea of how a multidimensional database is conceived has evolved over time. Basically, it can be said that an MDB is a set of multidimensional variables that, although they may refer to different sets of indicators, are related to each other because they share common points of view (dimensions).

As each multidimensional variable is structured in dimensions, each dimension in particular is characterized by a set of attributes that are in turn ordered according to a specific order relationship. The structure formed by this set of attributes and the corresponding order relationship is known as a hierarchy. The measures or indicators will be associated with the structure through a function: $h: D S \sim S S$ where DS (Dimensional Space) is the set of all possible coordinates that can be formed by crossing the dimensions, and SS (Scalar Space) is the set of all possible values that the indicators or measures can take. In this way, a multidimensional variable $H$ corresponds to the set $\{x / x=(d, e), d \in D S, e \in S S$, and $e=h(d)\}$ [34]. 
OLAP operators can be formally represented in multiple ways, some of them very sophisticated and difficult for most people to interpret and use. A [36] different way of defining the multidimensional data model and its operators is presented which, among its different characteristics, greatly simplifies the representation, syntax and functionality of OLAP operators, making the model much easier to understand and apply for different types of users.

Another relevant aspect is that the model proposed in [37] also contemplates the formal definition of the data classification mechanisms that are not entirely resolved by the simple definition of dimensions, hierarchies and measures. Although these structures constitute a formal basis to address the problem of data classification, it can be said that this need is an undeclared operator that underlies all multidimensional operators, even more so when many of the analytical activities require the transformation of domains, which implies not only selecting attributes of the dimensions, but also transforming them into new attributes, and such transformation requires an adequate conceptualization.

On the other hand, the Data Warehouse (DW), introduced in 1992, is the best-known way of implementing multidimensional databases in the production field [38]. It is a work environment supported by computer technology that, based on a combination of software and direct access storage technology, allows the implementation of an integrated, timevarying, non-volatile data collection, oriented to relevant topics for the management of an organization or company, which helps in their decision-making processes [39]. The purpose of the DW is the storage of homogeneous and reliable information. Its structure is oriented to queries, where the information receives hierarchical treatment in an environment differentiated from the operational systems [40].

For the implementation of a DW there are different alternatives where Multidimensional OLAP, Hybrid OLAP, Desktop OLAP, and Relational On-Line Analytical Processing (ROLAP) classically predominate, the latter being one of the most used because they take advantage of the good features of relational systems in their ability to retrieve and process data $[41,42]$.

The ROLAP approach has been extensively studied and developed, and there are widely spread methodologies that combine the multidimensional approach with the OLAP approach [43]. The same has not happened with the tools oriented to the conceptual modeling stage, which is characterized by not being conditioned to the characteristics of the model underlying the implementation tool. In this area, the product of the logical design process is commonly known as the star, snowflake, or constellation model.

OLAP and multidimensional databases are relevant for this work because they are part of the most suitable means to implement the computer component of the support system for monitoring the sustainability of Chilean ports.

\subsection{Motivation}

The motivation of this study is to know the main aspects that have been investigated in seaports related to strategies, businesses and sustainability indicators. At the same time, to determine the set of indicators and attributes that are decisive and useful to generate a proposal for a conceptual model of data and information flow to be shared among the actors that build the port system. The determination of said indicators will allow monitoring the degree of sustainability of the ports of Valparaíso and San Antonio. The model will be based on an information system supported by a multidimensional OLAP database that will handle indicators of economic, social and environmental aspects.

It should be highlighted that the ports studied currently do not have a monitoring system such as the one which is being proposed, so this research has the purpose of identifying the current situation and showing the need for more research in this area, in order to identify new sustainable variables and indicators that can transform the port into a more competitive one. 


\section{Sustainability in Chilean Ports Sustainable Strategies}

The European EcoPorts certification has begun to be implemented in Chilean public ports. Currently, only the port of Antofagasta complies with this international standard [44]. EcoPorts requires transparency in information and control regarding environmental management, reduction of fuel consumption, ship emissions, etc. [45].

As for the other ports to be under the certification process, they have not yet reached the so-called green stamps. The port of Valparaíso has implemented the the ISO 14,000 quality standard that evaluates environmental impacts; while the port of San Antonio signed the Agreement for Clean Production in Waste Management in 2020 to measure the carbon footprint specified on its indicators [46].

To identify what aspects of sustainability the ports of San Antonio and Valparaíso are concerned with, Table 1 displays the strategic phrases extracted from their web pages or memory documents. The strategic phrases classification is based on the dictionary created for this study [7], which includes the economic, social and environmental aspects of the macroenvironment of ports:

- Economic aspect (E): competitiveness, investment, infrastructure development, Governance decisions, productivity, technical entry barriers due to free competition and quality standards.

- $\quad$ Social aspect (S): social conflicts due to occupation of the city regulated by public organizations, port/city integration, delivery of added value to the city.

- Environmental aspect (A): environmental norms and standards, social responsibility.

Table 1. Strategic phrases and macro-environment aspects of the ports.

\begin{tabular}{|c|c|c|c|}
\hline Companies & Strategic Phrases & $\begin{array}{l}\text { Memory } \\
\text { Document }\end{array}$ & $\begin{array}{l}\text { Macro Environ- } \\
\text { ment Aspect }\end{array}$ \\
\hline $\begin{array}{l}\text { Port Administrator of } \\
\text { San Antonio }\end{array}$ & $\begin{array}{l}\text { "To efficiently and sustainably manage infrastructure, creating } \\
\text { value for foreign trade, taking care of the urban environment and } \\
\text { the environment ... to have active leadership in coordinating the } \\
\text { logistics chain and in the timely development of access roads" }\end{array}$ & [46] & $\mathrm{E}, \mathrm{S}, \mathrm{A}$ \\
\hline $\begin{array}{l}\text { Port Administrator of } \\
\text { Valparaíso }\end{array}$ & $\begin{array}{l}\text { "To guarantee sustainable development, ..., coordinate maritime } \\
\text { and land operations, manage improvements ... of infrastructure } \\
\ldots \text { improve the competitive position of the port and generate } \\
\text { shared value for the territory" }\end{array}$ & {$[44]$} & E, S, A \\
\hline Central Port Terminal & $\begin{array}{l}\text { "Port and logistics services of excellence, with a competent and } \\
\text { motivated team, adding value to our clients, taking care of people } \\
\text { and the environment" }\end{array}$ & [47] & E, S, A \\
\hline $\begin{array}{l}\text { San Antonio Interna- } \\
\text { tional Terminal }\end{array}$ & $\begin{array}{l}\text { "...Quality service, security, productivity and innovation } \\
\text {...improve the efficiency of the logistics chain and add value } \\
\text { to our clients, shareholders, collaborators and their families, pro- } \\
\text { moting community development and caring for the environment" }\end{array}$ & [48] & E, S, A \\
\hline Panul Port Terminal & $\begin{array}{l}\text { "To be the fundamental resource in the logistics chain of our } \\
\text { clients, providing an excellent and sustainable service" }\end{array}$ & [49] & E, S, A \\
\hline South Pacific Terminal & $\begin{array}{l}\text { "To be the best container port terminal in Latin America for the } \\
\text { development of our clients, collaborators and community. The } \\
\text { achievement of our objectives is based on a daily work for the } \\
\text { fulfillment of our values: Integrity, Excellence, Safety and Passion" }\end{array}$ & {$[50]$} & $\mathrm{E}, \mathrm{S}$ \\
\hline
\end{tabular}

Table 1 shows that despite the fact that almost all the administering companies that operate the terminals of the Port Communities of Valparaíso and San Antonio include the word "sustainability" in their strategies, they have not incorporated green seals. On the other hand, it is noted that the greatest strategic concern of companies in the short 
and medium term is about the economic aspect since they state as their main objectives to increase profitability and reduce the inefficiency in their logistics operations.

The critical factors to increase port competitiveness are identified in [6] and below: improving waiting times for land and maritime transport, reducing inventory costs, reducing operating costs, loading/unloading costs, and making information, data processes and communication more efficient.

When comparing the information in Table 1 with that of [7], it should be noted that the missions of the Port Community have been modified in the last five years and that the three aspects of the macroenvironment have been incorporated into the strategic phrases (economic, social and environmental).

The problems and challenges are diverse, standing out the following:

1. The different existing information platforms lack any integration, preventing the management, analysis and comparison of indicators at the level of each port and at global level as a single system.

2. Lack of procedures and protocols for the information flow among the different components of the port system, as well as with the State.

3. Greater lack of trust among the actors due to the absence of regulations that establish duties and rights for companies, workers and the State.

4. Non-existence of a body or institution that supports, promotes and is concerned with monitoring the degree of sustainability of the whole system, including ports and companies.

5. Lack of an information system that allows managing and exchanging information between the different port actors, as well as with the state.

6. Lack of an information system that allows each actor in the port system to manage its information, share it, know its degree of sustainability, and compare it to that in possession of other actors in the system.

This work constitutes a first step in the installation of a system that is capable of monitoring sustainable activities with interactive management, that increases the effectiveness of the production processes involved, improves the performance of resources, process big data, generates statistics and indicators that allow a clear visualization of the results and an efficient and effective evaluation of the business [51]. Its final implementation requires political/administrative agreements, economic resources, relatively long deadlines, an interdisciplinary work team, and a work plan that involves different actors.

\section{Hypothesis, Materials and Methods}

The hypothesis supporting this work is based on the fact that all the necessary conditions, for both the State and the Chilean port system, are currently available to establish the foundations, requirements and regulatory framework for a National Port Sustainability Monitoring System; including regulations and public policies that allow the management of a fundamental core of indicators, aimed at measuring the degree of sustainability of ports in particular and of the system in general. By integrating the information that is currently dispersed on different systems and independent platforms, it can be managed by an entity with a shared institutional framework between the State and private companies. This system would favor knowledge regarding the level of sustainability of companies to facilitate their self-assessment and identify their challenges, allowing them to compare themselves with similar companies and enabling integration and collaboration among all the actors in the system.

With the establishment of a National Port Sustainability Monitoring System, transparency can be provided to the management of the port business, it can help to achieve the levels of trust necessary to guarantee the continuity of the production processes, generate a healthy relationship between the company and the workers, and it can be replicated in similar port communities worldwide.

Consistent with this hypothesis, the following research objectives are raised: 
1. To carry out a study to identify strengths, weaknesses and risks related to the installation of port sustainability in the Chilean system.

2. To define the interaction mechanisms and the core of functionalities (at a macro level) related to the administrative information systems and technological tools necessary for the monitoring of port sustainability.

3. To design the conceptual and logic models of the multidimensional databases that will allow the subsequent implementation of the required computer systems.

The methodology begins with an analysis of the context of the Chilean port system and a study of other similar realities, documented in the technical and scientific literature. In this analysis, the needs that must be satisfied to generate the mechanisms for control, monitoring, comparison and exchange of information between the State and other actors of the port system were identified. As a result, a fundamental set of indicators related to the productive, environmental and labor spheres emerged, which reflect the degree of sustainability of a company, a port and the system in general. Special care has been taken to endow the system with a collaborative spirit between the State, the port system and, in particular, each private company that intervenes in the process; as well as determining specific aspects of the port system in order to establish the concept of port sustainability.

Based on the information gathered in the previous stages, the system was designed by identifying its components, characteristics, and the interactions between its components. State agencies, legal frameworks and regulatory mechanisms were incorporated. As a result of the institutional responsibilities and operational activities that are developed and established among the different components, a mixed, public/private body, called the National Council of Port Sustainability, was introduced in the design. In a more specific scope of the port system, public and private companies were introduced; the instances of interaction among them were defined, as well as other organisms not necessarily productive, but determining in the context, such as the Chilean Security Association (ACHS).

Having clarified the components of the system, the interactions between the actors, and the flow of information, we proceeded to define the multidimensional database that will be the foundation on which the computer tools destined to provide administrative technological support to the National Sustainability Council will be built. The design of the required multidimensional variables is presented in this document at a logical level, so its implementation can be carried out in multiple environments, either using free software tools or proprietary software.

The data sources shown in Table 2 are studied to design a set of indicators that are applicable to the reality of the ports of Valparaíso and San Antonio, and that are feasible to implement in an OLAP model.

Table 2. Digital repositories.

\begin{tabular}{|c|c|c|}
\hline Repositories & Characteristics of the Databases & Website \\
\hline $\begin{array}{l}\text { National Information System for } \\
\text { Environmental Enforcement }\end{array}$ & Environmental complaints & $\begin{array}{l}\text { https://portal.sma.gob.cl (accessed on } \\
15 \text { January 2021) }\end{array}$ \\
\hline Centralized Government Data Portal & $\begin{array}{l}\text { Unique entry documents. } \\
\text { Single exit documents }\end{array}$ & $\begin{array}{l}\text { https:/ / datos.gob.cl (accessed on } \\
15 \text { January 2021) }\end{array}$ \\
\hline Logistics observatory & Marine transport & $\begin{array}{l}\text { https:/ / www.observatoriologistico.cl } \\
\text { (accessed on } 15 \text { January 2021) }\end{array}$ \\
\hline $\begin{array}{l}\text { General Directorate of the Maritime } \\
\text { Territory and Merchant Marine }\end{array}$ & $\begin{array}{l}\text { Work accidents. } \\
\text { Ship and cargo movement. }\end{array}$ & $\begin{array}{l}\text { https: / / www.directemar.cl (accessed } \\
\text { on } 15 \text { January 2021) }\end{array}$ \\
\hline Ministry of Health & Work accidents & $\begin{array}{l}\text { https:// deis.minsal.cl (accessed on } \\
15 \text { January 2021) }\end{array}$ \\
\hline
\end{tabular}

\section{System for Monitoring the Sustainability of Chilean Ports}

This document presents a conceptual proposal for a monitoring system with indicators that measure the critical aspects of sustainability of the ports of Valparaíso and San 
Antonio. Based on the collection of relevant information, the system comprises: (1) the port community, made up of private companies that manage, operate and provide logistics services to the port, (2) the ACHS that manages insurance for accidents at work and (3) the Public Ministries that regulate and oversee the port business, in accordance with the current legal framework.

\subsection{Conceptual Modelling Proposal}

The system consists of a set of standards, interaction procedures and computer tools that can be installed in the work environment or ecosystem of any port system, designed to implement the port sustainability approach and its maintenance over time. The various components of the system can be classified into three areas: those related to the State, to the port communities, and the National Commission for Port Sustainability.

The responsibility of the State is to provide the necessary institutional framework to give legal support to the System; particularly, the generation of laws and regulations, the coordination of public agencies related to the port community and the creation of the legal framework for the Creation of the National Commission for Port Sustainability.

In the area of port communities, monitoring protocols to help decision-making are established for the private companies system. The framework of regulations and public policies will favor integration, coordination, and trust between workers, unions, and ports; as well as the adequate coordination with the ACHS. The different actors that intervene in this area assume the commitment to provide the information the system needs to measure sustainable management with the use of indicators. This process is carried out through the computer tools related to Business Intelligence that Extract, Transform and Load (ETL) the data to transform it into information and knowledge [52]. The computer tools will be available to public organizations linked to ports and private companies that are authorized by law.

The third area, the National Port Sustainability Commission, is a mixed composition entity (public and private), where representatives of the State, the port community and the ACHS participate. This is the logistics forum where different problems arising from the processes and how they affect sustainability goals are discussed, to generate solutions that the State must legislate. The Commission is also in charge of ensuring the correct functioning of the computer tools that allow the management of the indicators. These tools will provide management reports that contribute to decision making.

The degree of compliance with sustainability is determined by the value achieved of a basic set of measures, which reflect sensitive information for the decision-making of the port business in the social, economic and environmental aspects. The indicators considered in this proposal are:

- $\quad$ Average daily hours performed by activity type and load type.

- $\quad$ Average daily clients served by activity type and load type.

- $\quad$ Average profit by activity type and load type.

- $\quad$ Average expenses by activity type and load type.

- $\%$ of average profit by activity type and load type.

- $\quad \%$ of average expenses by activity type and load type.

- $\quad$ Average of a certain accident type.

- Average number of workers involved in a certain accident type.

- Number of companies involved in a certain accident type.

- Number of ships (boats) involved in a certain accident type.

- Number of vehicles involved in a certain accident type.

- Average of fines issued for a certain accident type.

- Average amount paid in fines for a certain accident type.

- Average of inputs of a certain type used in the development of port operations.

- $\%$ of inputs used with respect to the total activities in the development of port operations.

- Number of clients benefited from the use of a certain type of resource. 
- Total emissions derived from combustion (for example, $\mathrm{PTS}, \mathrm{NO}_{\mathrm{X}}, \mathrm{CO}, \mathrm{SO}_{\mathrm{X}}, \mathrm{NMVOC}$, $\mathrm{CH}_{4}, \mathrm{~N}_{2} \mathrm{O}, \mathrm{CO}_{2}$ ).

- Noise generation Level.

- Total other greenhouse gas emissions (GHG).

- $\quad \%$ Hazardous and non-hazardous spills.

Communication between the different actors will require the establishment of a protocol that regulates the time, magnitude and quality of the information that must be sent to the system or from other systems (Figure 1). The system must be framed in the current legislation, monitoring and reflecting the changes that may occur over time in this matter, so that public policies can be updated.

The information is stored and managed in a multidimensional database, which will allow analytical facilities to monitor the system.

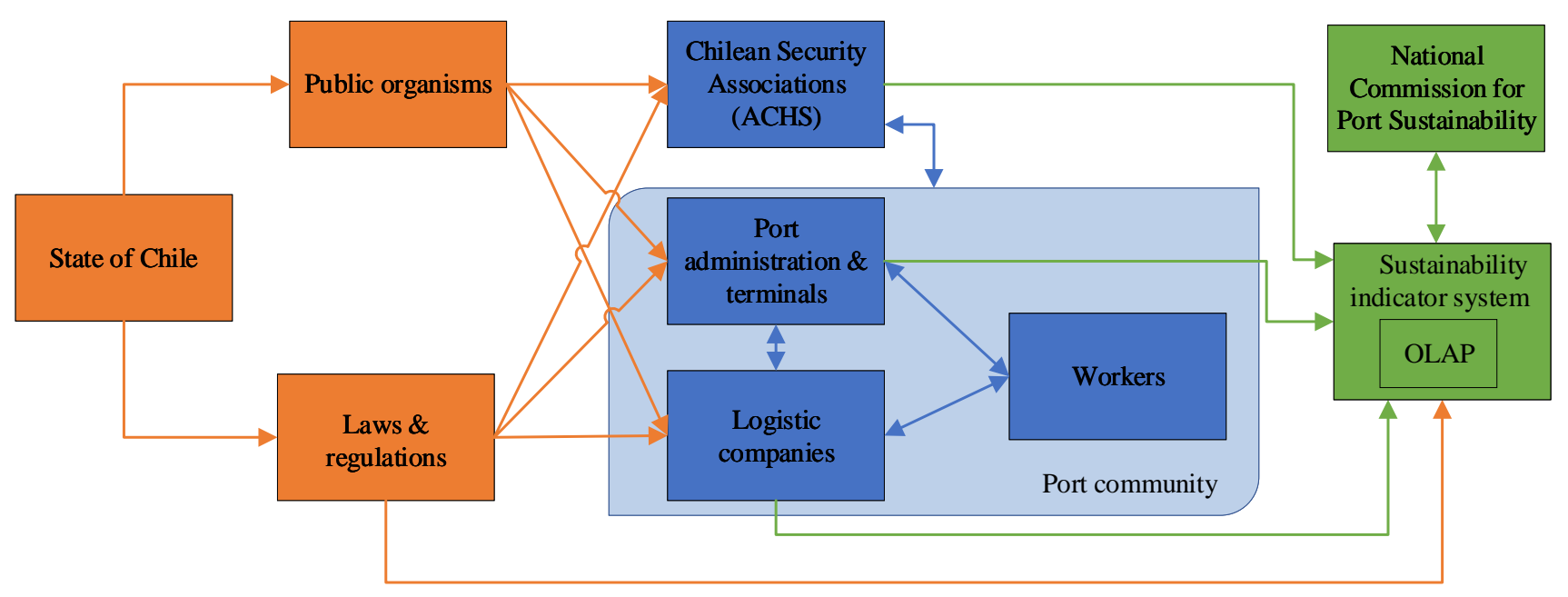

Figure 1. Port system context.

\subsection{System Operation}

As shown in Figure 2, the installation of this system generates a new flow of information for port actors. The architecture begins with the State and the ACHS, the former approves the legal and regulatory structure and the latter, according to Law $\mathrm{N}^{\circ} 16,744$, covers medical and economic benefits in the event of occupational accidents or occupational disease. Through the regulatory framework of the State, procedures are established for the National Port Sustainability Commission, which interacts with the Port Community, making decisions based on the sustainability indicators provided by the system.

In this new scenario, companies and the various components of the system begin to adapt their protocols and procedures. It begins with the registration of activities necessary for monitoring sustainability actions, through interfaces that feed a properly structured ETL process, that will allow the multidimensional database of the information system to be populated with all the required information. The system will offer the different actors personalized reports online; so, they will be able to make preventive decisions in an effective way, reducing the response times related to transportation, inventory, storage, supply and administration that are so critical and expensive in the ports of Valparaíso and San Antonio. Based on the strengths, weaknesses, opportunities or threats detected in the environment, the National Port Sustainability Commission will generate proposals for regulatory, procedural and protocol modifications, thus transforming itself into a system of continuous improvement. 


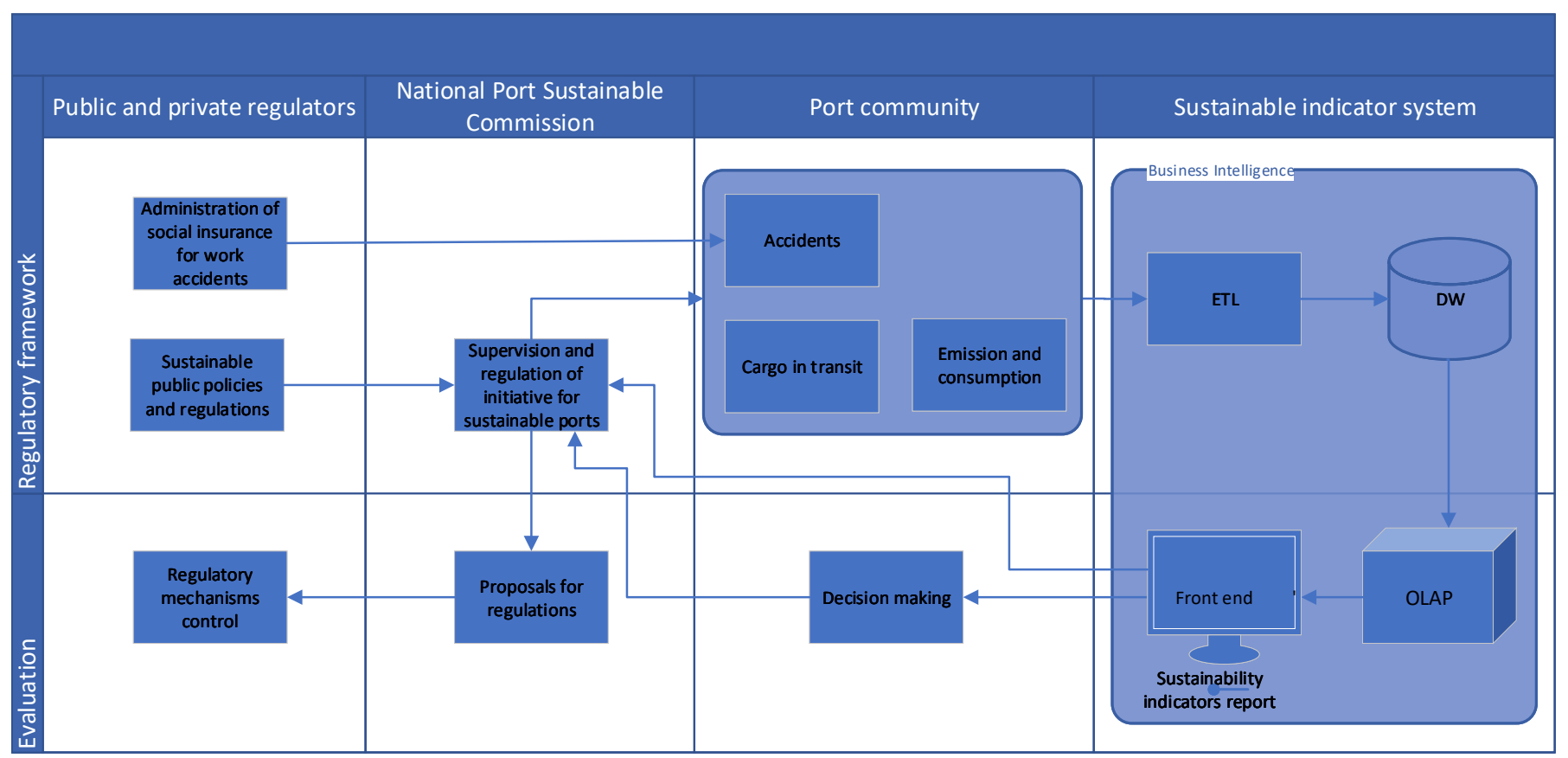

Figure 2. Sustainable port architecture (abbreviations in the Figure: Extract, Transform and Load (ETL), Data Warehouse (DW), On-Line Analytical Processing (OLAP)).

\subsection{OLAP Subsystem and Multidimensional Database}

An essential component of the proposed solution consists of the implementation of one or more information systems destined to carry out multidimensional analysis on the indicators selected in the Port Sustainability Monitoring System. Said systems should be implemented in a web environment and be provided by the National Port Sustainability Council. If necessary, depending on the nature of the activities carried out, mobile applications for smartphones and tablets could also be implemented.

The main function of the multidimensional subsystem is to allow the analytical process of the indicators considered in the system, since they will be contained in a single multidimensional database. Not only analytical facilities will be guaranteed, but also the coherence of the data, and that all users will have the same online updated information.

After the indicators have been analyzed and transformed into additive indicators, considering the different perspectives or analysis of needs as required by the system, the indicators are implemented in three different multidimensional variables, as shown in Figure 3. The accident rate variable focuses on measuring indicators related to the accident rate that is recorded in the operations of each port during the performance of different types of activities. The consumption variable is focused on measuring indicators related to the consumption of inputs or other types of resources during the daily activities of the ports. The efficiency variable focuses on measuring indicators related to the efficiency of each port in carrying out the different types of activities, considering a daily load type. 


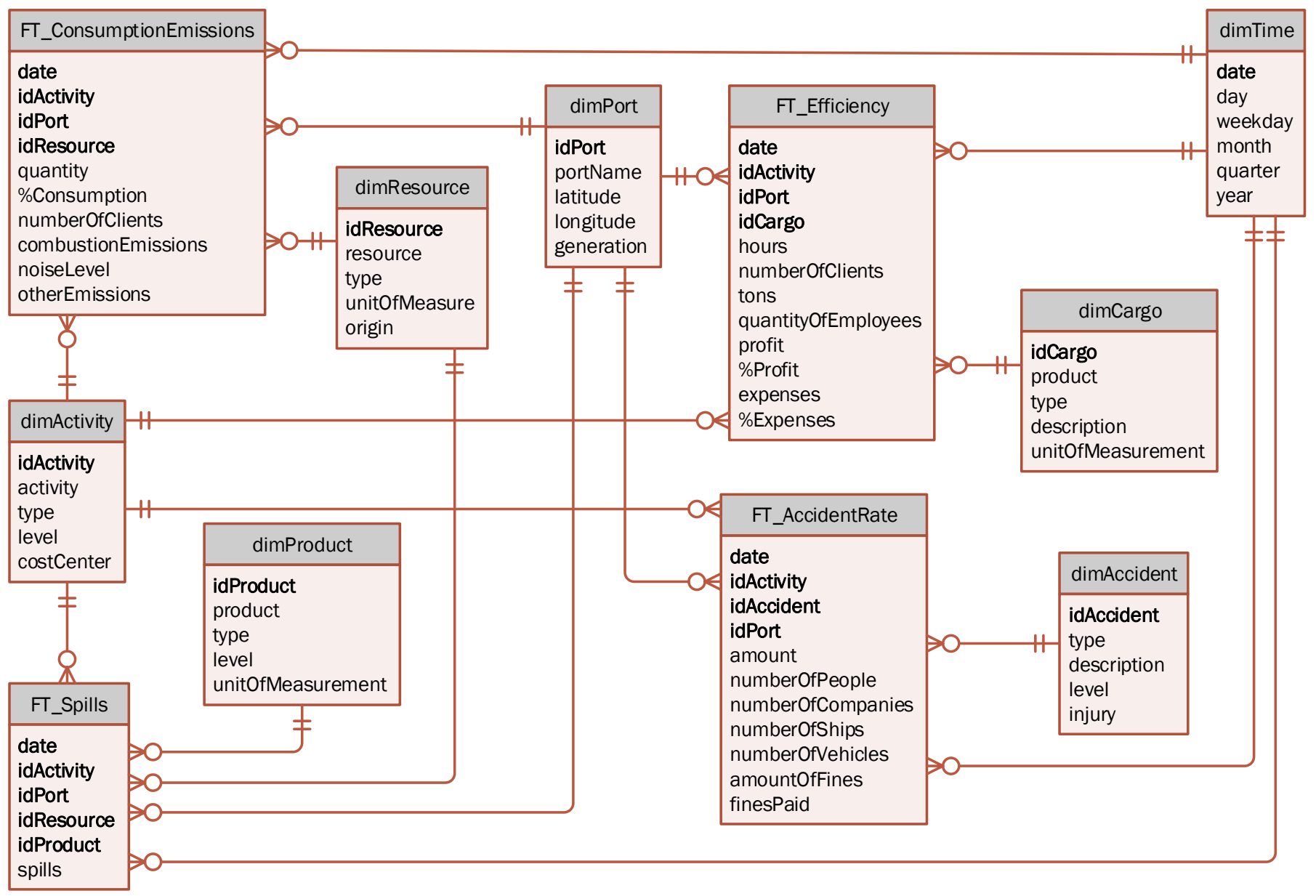

Figure 3. Logic model for the multidimensional database.

\subsection{Decomposition of Indicators into Additive Expressions}

OLAP systems usually work by performing direct operations on multidimensional variables, which are designed with maximum granularity in each of the attributes of the hierarchies that make up each of the dimensions of the variables. However, many queries require different levels of aggregation with higher summarizations; which implies that many queries require significant processing efforts, obtaining temporary results that will be discarded later. Since this practice can be very harmful to a system, where the queries are frequently repeated and, in turn, involve considerable amounts of data; a new multidimensional structure, called the Aggregate Fact Family (AFF) was introduced, consisting of a pair made up of a certain multidimensional variable and a certain multiple aggregation function. Its purpose is to avoid unnecessary computations by storing certain intermediate results that are usually required in different queries. This is achieved by decomposing the indicators, where possible, into additive functions that fulfill the additive property. For this reason, the design of the database proposed in this work, in order to prepare the system for a future implementation of AFF on the variables of the database, contemplates indicators that are obtained directly from additive functions [36,37].

Section 4.1 shows the indicators to be used, where each and every one of them complies with the additive property as defined in [37], which establishes that a function is additive if "given two compatible sets $\xi_{1}$ and $\xi_{2}$, such that $\xi_{1} \cap \xi_{2}=\phi$, then $f$ is additive if and only if: $f\left(\xi_{1} \cup \xi_{2}\right)=f\left(\xi_{1}\right)+f\left(\xi_{2}\right)$.

For the calculation of the indicators, a large amount of transactional data is required which can be summarized and grouped into a multidimensional structure, allowing an easy access from OLAP databases [53-55]. 
In the case of this proposal, the database requires a total of four fact tables and seven dimensions, which are sufficient to store all the necessary indicators. A great part of the summarizations will be carried out in the ETL process since the database constitutes a robust aggregate information source.

Table 3 corresponds to the so-called Kimball bus matrix [56], necessary for the beginning of the implementation of the DW, which is useful as a guide, to prioritize the development of thematic areas and identify the potential scope of its dimensions. This allows displaying how the selected dimensions are related to sustainability processes.

Table 3. Matrix bus for the DW of port sustainability.

\begin{tabular}{lccccccr}
\hline \multirow{2}{*}{ Processes } & \multicolumn{7}{c}{ Dimension } \\
\cline { 2 - 7 } & Time & Accident & Activity & Port & Cargo & Resource & Product \\
\hline Efficiency & $\mathrm{X}$ & & $\mathrm{X}$ & $\mathrm{X}$ & $\mathrm{X}$ & & \\
Accident rate & $\mathrm{X}$ & $\mathrm{X}$ & $\mathrm{X}$ & $\mathrm{X}$ & & $\mathrm{X}$ & \\
Consumption and emissions & $\mathrm{X}$ & & $\mathrm{X}$ & $\mathrm{X}$ & & $\mathrm{X}$ & $\mathrm{X}$ \\
Spills & $\mathrm{X}$ & & $\mathrm{X}$ & $\mathrm{X}$ & & $\mathrm{X}$ & \\
\hline
\end{tabular}

\section{Discussion}

\subsection{Port Strategies}

When studying the strategic phrases of the two public Chilean ports that have the highest cargo movement $[44,46-50,57]$ and comparing them with [6], it is observed that the strategic port concern for sustainability has increased in the last 5 years, and that the ports operate with some sustainable aspects. Currently, the Port Communities of Valparaíso and San Antonio propose the following words in their missions:

- Economic (E): sustainability, industry, country development, trade, security.

- Social (S): collaborate, client, family.

- Environment (A): sustainability.

It should be noted that the strategic words have changed and that it is necessary to incorporate more attributes related to the definition of sustainability that was raised in Section 1 . This is because it is required a long-term public policy that encourages a cultural change; not only of the companies that operate and administer the ports, but rather the actors that build the network.

On the other hand, as they are publicly owned ports concessioned to private companies, it is difficult to make high investments in infrastructure and technology that facilitate the implementation of a green port. This is due to the fact that the companies are not autonomous, since they depend on the approval of the annual budget of the Public Company Systems Commission, after the resources are approved and a decree law is created [6].

Another important factor to consider is the technological development of the mediumsized ports studied, which is at the initial stage. They are classified as Industry 3.0 with some attributes of Industry 4.0, and some of their characteristics can be mentioned such as: they are automated, they operate with technological systems and communications, with the Internet of Things, clouds, social networks and large databases [58]. There are important gaps when compared to green ports or industries 4.0, since they have an advanced technological development and operate with artificial intelligence, blockchain, big data and other disruptive technologies [27].

Due to all the mentioned reasons, this paper provides a conceptual proposal aimed at generating the necessary conditions for efficient and transparent management and monitoring, generating the necessary climate to promote trust among the actors of the port system. It is noted that before selecting the sustainability indicators that are shown in Section 4.1 and that are the basis of the proposed conceptual model, the data repositories in Table 2 were reviewed to assess whether with the available data and variables it was feasible to perform the modeling. 
Finally, installation requires adequate physical and technological port infrastructure accompanied with effective public policies that follow the international standards.

\subsection{Conceptual Validation of the System}

Table 4 was created based on the information collected in documents [7,59-62] and a bibliographic review. The relevant characteristics of the main actors that build the proposed conceptual model are selected. The table presents a comparison between the current state and a five-year scenario, with and without a National Port Sustainability Monitoring System. The relevance of the projection lies in making a comparison between the second and third column where the impact on the port system is predicted, if the OLAP model is implemented and the State incorporates it into public policies.

Table 4. Comparison of two possible implementation scenarios of the OLAP model.

\begin{tabular}{lll}
\hline \multirow{2}{*}{ Current Situation } & \multicolumn{1}{c}{ In Five or More Years } \\
\cline { 2 - 3 } & No System & With System \\
\hline
\end{tabular}

State:

- There is a general regulatory framework that establishes environmental protocols, labor laws and statutory regulations for public, concessioned and private ports [63].

- Lack of an organism that ensures sustainability in the national port activity. Concern about the environmental impact of port operations [4].
- Probable improvements in the regulatory framework [64].

- Probably more active participation in international forums [64].

- Stability in labor laws that can potentially allow the generation of conflicts between companies, ports and workers [65].

- Stability in the statutory regulations governing the different types of ports [66].

- Lack of an organism that ensures sustainability in the national port activity [64].
- A new regulatory framework that regulates port activity guaranteeing sustainability [67].

- Leadership in international forums as a result of the implementation of a new regulatory framework that establishes goals and regulates port activity to ensure sustainability [68].

- A new regulation between workers and companies that establishes duties and rights of workers, operational stability for companies and ports, as well as a better productive environment [4].

- Existence of the National Commission for Sustainability Assurance.

- Integrated computer system to measure sustainability in ports and related companies.

- Computer system that provides data to support international commitments on sustainability [69].

\section{Enterprises:}

- Regulatory framework that establishes operating and statutory regulations for companies not necessarily linked to sustainability criteria [70].

- Low prioritization of remedial actions regarding the environmental impact of port operations [71]
- Regulatory framework of operational and statutory regulations for ports with a probable greater emphasis on sustainability criteria [72].

- Probable improvements in the regulatory framework related to the environmental impact of port operations [16].

- Greater pressure from the State regarding the environmental impact of port operations [63].
- A new regulatory framework that ensures the sustainability of port activity.

- Regulations establishing labor and environmental criteria that guarantee competitiveness under equal conditions [73].

- Very significant decrease in the environmental impact of port operations.

- Better relationship with workers, higher productivity and better standards.

- Significantly better relationship between companies and ports with the communities that host them [4].

- Integrated computer system that allows a company to share information with the State, as well as to measure its degree of sustainability and compare itself to the rest of them [74].
- Regulatory framework that establishes operational and statutory regulations for ports, not necessarily linked to sustainability criteria [70].

- Little concern about the environmental impact of port operations [75].
- Regulatory framework of operational and statutory regulations for ports with a probable greater emphasis on sustainability criteria [72].

- Probable improvements in the regulatory framework related to the environmental impact of port operations [16].

- Greater pressure from the State regarding the environmental impact of port operations [63].
- Knowledge and implementation of the new regulatory framework for port activities that require sustainability in their operations [64]. - Port activities are completely framed within the regulations that guarantee an adequate relationship with the environment [4].

- Excellent relationship between the ports and the communities that host them.

- Integrated computer system that allows a port to share information with the State, as well as to measure its degree of sustainability and compare itself to the rest of the ports [71]. 
Table 4. Cont.

\begin{tabular}{lll}
\hline \multirow{2}{*}{ Current Situation } & In Five or More Years \\
\cline { 2 - 2 } & No System & With System \\
\hline
\end{tabular}

Workers:

- Existence of a national regulatory framework related to port labor activity [76].
- Stagnation in the national regulatory framework related to port labor activity [76].

- Moderate risk of labor disputes between companies, ports and workers [65].

- Non-existence of instances for job training in harmony with companies and the state [77].

\section{Conclusions}

This research identified the main characteristics that ports must have at the general level so that they can be classified as sustainable or green ports. It is noted that there are varying degrees of sustainability development in the port industry and that for a port to be green, it is required to meet multiple aspects of the macro and micro environment that regulate the impacts that are generated on port operations.

Implementing sustainability requires a cultural change from all private and public actors that build the port network, in which there are trust and international commitments; protocols, regulations and standards to be met. Also, new public policies and strategies are needed that promote respect for the environment, the relationship with the inhabitants of the city the port occupies, the use of technology, international trade, among others.

In this work the strategies of the Chilean ports of Valparaíso and San Antonio were studied. It was noted that although they are not certified as EcoPorts, words related to the social, economic and environmental aspects are being included in their corporate missions. This shows that there is an interest in incorporating sustainability into port business, in order to comply with the state's strategic planning for 2030, with the National Clean Production Program in energy efficiency, and with the International Convention for the Prevention of Pollution from Ships [59,79].

A conceptual modelling is proposed consisting of a monitoring system that is useful for decision-making and management control with sustainable indicators related to occupational accidents, cargo movement and emissions. With regard to the viability of model development, as shown in Figure 2, it is feasible to do so as it is based on freely available databases that can feed and power the system. It can be concluded that it is an effective, reliable and timely tool that allows monitoring the flow of data and that; if implemented, it would allow the collection of information that contributes to the creation of new sustainable initiatives to improve the Chilean port business. On the other hand, it could provide the State with information needed to create new regulations and public policies. To be realized, it must include a new player in the Chilean port system: the National Commission for Port Sustainability. This entity will have the function of coordinating actions with public services for the generation of laws and regulations.

Finally, it is necessary to continue with this investigation line, searching for new variables and indicators to better define the degree of sustainability that a port possess, and the gaps they must fulfill in order to achieve the "green port" status.

Author Contributions: Conceptualization, C.D., F.P. and R.C.; Data curation, F.P. and E.C.; Formal analysis, C.D., F.P. and R.C.; Funding acquisition, C.D.; Investigation, C.D., F.P., R.C. and E.C.; Methodology, C.D., F.P. and R.C.; Project administration, C.D.; Supervision, C.D.; Validation, F.P. and R.C.; Visualization, F.P. and R.C.; Writing-original draft, C.D., F.P., R.C. and E.C.; Writing-review \& editing, C.D., F.P., R.C. and E.C. All authors have read and agreed to the published version of the manuscript. 
Funding: Project supported by the Competition for Research Regular Projects, year 2019, code LPR19-19, Universidad Tecnológica Metropolitana.

Institutional Review Board Statement: Not applicable.

Informed Consent Statement: Not applicable.

Data Availability Statement: Not applicable.

Conflicts of Interest: The authors declare that there is no conflict of interest in the publication of this paper.

\begin{tabular}{|c|c|}
\hline \multicolumn{2}{|c|}{ Abbreviations } \\
\hline \multicolumn{2}{|c|}{$\begin{array}{l}\text { Abbreviations } \\
\text { The following abbreviations are used in this manusct }\end{array}$} \\
\hline \\
\hline \\
\hline \multicolumn{2}{|l|}{ DW } \\
\hline \multirow{2}{*}{$\begin{array}{l}\text { ETL } \\
\text { MDB }\end{array}$} & Extract, Transform and Load \\
\hline & Multidimensional Database \\
\hline \multirow{2}{*}{ OLAP } & On-Line Analytical Processing \\
\hline & Relational On-Line Analytical Processin \\
\hline
\end{tabular}

\section{References}

1. Parola, F.; Risitano, M.; Ferretti, M.; Panetti, E. The drivers of port competitiveness: A critical review. Transp. Rev. 2017, 37, 116-138. [CrossRef]

2. Acciaro, M. Corporate responsibility and value creation in the port sector. Int. J. Logist. Res. Appl. 2015, 18, 291-311. [CrossRef]

3. Oh, H.; Lee, S.W.; Seo, Y.J. The evaluation of seaport sustainability: The case of South Korea. Ocean Coast. Manag. 2018, 161, 50-56. [CrossRef]

4. Hossain, T.; Adams, M.; Walker, T.R. Sustainability initiatives in Canadian ports. Mar. Policy 2019, 106, 103519. [CrossRef]

5. Darbra, R.M.; Wooldridge, C.; Puig, M. ESPO Environmental Report 2020: EcoPortsinsights 2020; European Sea Ports Organisation: Brussels, Belgium, 2020; p. 30.

6. Durán, C.A.; Córdova, F.M.; Palominos, F. Method for improving critical strategic and operational success factors in a port system. Procedia Comput. Sci. 2018, 139, 448-455. [CrossRef]

7. Duran, C.A.; Cordova, F.M. Conceptual Model to Identify Technological Synergic Relationships of Strategic Level in a Mediumsized Chilean Port. Procedia Comput. Sci. 2016, 91, 382-391. [CrossRef]

8. Lam, J.S.; Yap, W.Y. A Stakeholder Perspective of Port City Sustainable Development. Sustainability 2019, 11, 447. [CrossRef]

9. Hossain, T.; Adams, M.; Walker, T.R. Role of sustainability in global seaports. Ocean Coast. Manag. 2020, 105435. [CrossRef]

10. Durán, C.; Sepulveda, J.; Carrasco, R. Determination of technological risk influences in a port system using DEMATEL. Decis. Sci. Lett. 2018, 7, 1-12. [CrossRef]

11. Durán, C.; Carrasco, R.; Sepúlveda, J.M. Model of decision for the management of technology and risk in a port community. Decis. Sci. Lett. 2018, 7, 211-224. [CrossRef]

12. Sislian, L.; Jaegler, A.; Cariou, P. A literature review on port sustainability and ocean's carrier network problem. Res. Transp. Bus. Manag. 2016, 19, 19-26. [CrossRef]

13. Lu, C.S.; Lai, P.L.; Chiang, Y.P. Container terminal employees' perceptions of the effects of sustainable supply chain management on sustainability performance. Marit. Policy Manag. 2016, 43, 597-613. [CrossRef]

14. Yuen, K.F.; Thai, V.V. Corporate social responsibility and service quality provision in shipping firms: financial synergies or trade-offs? Marit. Policy Manag. 2017, 44, 131-146. [CrossRef]

15. Österman, C.; Rose, L. Assessing financial impact of maritime ergonomics on company level: a case study. Marit. Policy Manag. 2015, 42, 555-570. [CrossRef]

16. Vejvar, M.; Lai, K.h.; Lo, C.K.Y.; Fürst, E.W.M. Strategic responses to institutional forces pressuring sustainability practice adoption: Case-based evidence from inland port operations. Transp. Res. Part D Transp. Environ. 2018, 61, 274-288. [CrossRef]

17. Poulsen, R.T.; Ponte, S.; Lister, J. Buyer-driven greening? Cargo-owners and environmental upgrading in maritime shipping. Geoforum 2016, 68, 57-68. [CrossRef]

18. Ha, M.H.; Yang, Z. Comparative analysis of port performance indicators: Independency and interdependency. Transp. Res. Part A Policy Pract. 2017, 103, 264-278. [CrossRef]

19. Bae, H.S. The Effect of Environmental Capabilities on Environmental Strategy and Environmental Performance of Korean Exporters for Green Supply Chain Management. Asian J. Shipp. Logist. 2017, 33, 167-176. [CrossRef]

20. Hua, C.; Chen, J.; Wan, Z.; Xu, L.; Bai, Y.; Zheng, T.; Fei, Y. Evaluation and governance of green development practice of port: A sea port case of China. J. Clean. Prod. 2020, 249, 119434. [CrossRef] 
21. Roos, E.C.; Kliemann Neto, F.J. Tools for evaluating environmental performance at Brazilian public ports: Analysis and proposal. Mar. Pollut. Bull. 2017, 115, 211-216. [CrossRef]

22. González Laxe, F.; Bermúdez, F.M.; Palmero, F.M.; Novo-Corti, I. Sustainability and the Spanish port system. Analysis of the relationship between economic and environmental indicators. Mar. Pollut. Bull. 2016, 113, 232-239. [CrossRef] [PubMed]

23. Heilig, L.; Lalla-Ruiz, E.; Voß, S. Digital transformation in maritime ports: analysis and a game theoretic framework. Netnomics Econ. Res. Electron. Netw. 2017, 18, 227-254. [CrossRef]

24. Elia, V.; Gnoni, M.G.; Tornese, F. Measuring circular economy strategies through index methods: A critical analysis. J. Clean. Prod. 2017, 142, 2741-2751. [CrossRef]

25. Linder, M.; Sarasini, S.; van Loon, P. A Metric for Quantifying Product-Level Circularity. J. Ind. Ecol. 2017, 21, 545-558. [CrossRef]

26. Stindt, D. A generic planning approach for sustainable supply chain management-How to integrate concepts and methods to address the issues of sustainability? J. Clean. Prod. 2017, 153, 146-163. [CrossRef]

27. Kapkaeva, N.; Gurzhiy, A.; Maydanova, S.; Levina, A. Digital Platform for Maritime Port Ecosystem: Port of Hamburg Case. Transp. Res. Procedia 2021, 54, 909-917. [CrossRef]

28. Cammin, P.; Yu, J.; Heilig, L.; Voß, S. Monitoring of air emissions in maritime ports. Transp. Res. Part D Transp. Environ. 2020, 87, 102479. [CrossRef]

29. Lee, P.T.W.; Lee Lam, J.S.; Lin, C.W.; Hu, K.C.; Cheong, I. Developing the fifth generation port concept model: An empirical test. Int. J. Logist. Manag. 2018, 29, 1098-1120. [CrossRef]

30. Cuzzocrea, A.; Moussa, R. Multidimensional database modeling: Literature survey and research agenda in the big data era. In Proceedings of the 2017 International Symposium on Networks, Computers and Communications (ISNCC), Marrakech, Morocco, 16-18 May 2017; pp. 1-6. [CrossRef]

31. Chavan, R.; Nehe, R. Analysis of Data Warehousing and OLAP Technology. 2017; pp. 225-231. Available online: ici2tm.sinhgad. edu (accessed on 21 December 2020).

32. Jaroli, P.; Masson, P. Data Warehousing and OLAP Technology (Data warehousing). Int. J. Eng. Trends Technol. 2017, 51, 45-50. [CrossRef]

33. Neha, K.G. Efficient Information Retrieval Using Multidimensional OLAP Cube. Int. Res. J. Eng. Technol. 2017, 4, $2885-2889$.

34. Palominos, F.; Durán, C.; Córdova, F. Multidimensional data model for the analysis of information of productive, scientific or service processes. In Proceedings of the 2018 7th International Conference on Computers Communications and Control (ICCCC), Oradea, Romania, 8-12 May 2018; pp. 17-22. [CrossRef]

35. Kimball, R. A Dimensional Modeling Manifesto. DBMS 1997, 10, 58-70.

36. Palominos, F.E.; Durán, C.A.; Córdova, F.M. Improve efficiency in multidimensional database queries through the use of additives aggregation functions. Procedia Comput. Sci. 2019, 162, 754-761. [CrossRef]

37. Palominos, F.E.; Córdova, F.; Durán, C.; Nuñez, B. A Simpler and Semantic Multidimensional Database Query Language to Facilitate Access to Information in Decision-making. Int. J. Comput. Commun. Control 2020, 15. [CrossRef]

38. Inmon, W.H. Building the Data Warehouse, 4th ed.; John Wiley \& Sons, Inc.: Indianapolis, IN, USA, $2005 ;$ p. 576.

39. Alsahfi, T.; Almotairi, M.; Elmasri, R. A Survey on Trajectory Data Warehouse. Spat. Inf. Res. 2020, 28, 53-66. [CrossRef]

40. Boulil, K.; Bimonte, S.; Pinet, F. Conceptual model for spatial data cubes: A UML profile and its automatic implementation. Comput. Stand. Interfaces 2015, 38, 113-132. [CrossRef]

41. Wrembel, R.; Abelló, A.; Song, I.Y. DOLAP data warehouse research over two decades: Trends and challenges. Inf. Syst. 2019, 85, 44-47. [CrossRef]

42. Santos, M.Y.; Martinho, B.; Costa, C. Modelling and implementing big data warehouses for decision support. J. Manag. Anal. 2017, 4, 111-129. [CrossRef]

43. Kimball, R.; Ross, M. The Data Warehouse Toolkit: The Definitive Guide to Dimensional Modeling, 3rd ed.; John Wiley \& Sons, Inc.: Indianapolis, IN, USA, 2013; p. 608.

44. Empresa Portuaria Valparaíso. Memoria anual Empresa Portuaria Valparaíso 2019; Technical Report; Empresa Portuaria Valparaíso: Valparaíso, Chile, 2020.

45. Balbaa, A.; Swief, R.A.; El-Amary, N.H. Smart Integration Based on Hybrid Particle Swarm Optimization Technique for Carbon Dioxide Emission Reduction in Eco-Ports. Sustainability 2019, 11, 2218. [CrossRef]

46. Puerto San Antonio. Memoria Anual 2019; Technical Report; Puerto San Antonio: San Antonio, Chile, 2020.

47. San Antonio Terminal Internacional S.A. Memoria Anual 2019; Technical Report; San Antonio Terminal Internacional S.A.: San Antonio, Chile, 2020.

48. sti San Atonio Terminal Internacional. Who We Are: Mission Vision ans Values. 2021. https://www.stiport.com/quienes_somos/ mision/index.php (accessed on 6 February 2021).

49. Puerto Panul. La Empresa: Visión y Misión. 2021. http://www.puertopanul.cl/vision.php (accessed on 6 February 2021).

50. Terminal Pacifico Sur Valparaíso S.A. Terminal Pacifico Sur Valparaíso SA.-TPS: Desarrollo y Comercio Internacional. 2021. https: //www.linkedin.com/company/terminal-pacifico-sur-valparaiso-s-a- / ?originalSubdomain=cl (accessed on 6 February 2021).

51. Özispa, N.; Arabelen, G. Assessment of port sustainability indicators in the sustainability reporting process. Beykoz Akad. Derg. 2018, 6, 1-28. [CrossRef]

52. Zerbino, P.; Aloini, D.; Dulmin, R.; Mininno, V. Towards Analytics-Enabled Efficiency Improvements in Maritime Transportation: A Case Study in a Mediterranean Port. Sustainability 2019, 11, 4473. [CrossRef] 
53. Chan, S.H.; Song, Q.; Sarker, S.; Plumlee, R.D. Decision support system (DSS) use and decision performance: DSS motivation and its antecedents. Inf. Manag. 2017, 54, 934-947. [CrossRef]

54. García, S.; Romero, O.; Raventós, R. DSS from an RE Perspective: A systematic mapping. J. Syst. Softw. 2016, 117, 488-507. [CrossRef]

55. Bouakkaz, M.; Ouinten, Y.; Loudcher, S.; Strekalova, Y. Textual aggregation approaches in OLAP context: A survey. Int. J. Inf. Manag. 2017, 37, 684-692. [CrossRef]

56. Kimball, R.; Ross, M. The Kimball Group Reader: Relentlessly Practical Tools for Data Warehousing and Business Intelligence, 2nd ed.; Wiley Online Books, John Wiley \& Sons, Inc.: Indianapolis, IN, USA, 2015; p. 912. [CrossRef]

57. ZEAL Sociedad Concesionaria S.A. Acerca de Zeal. 2021. https:/ / www.zeal.cl/acerca-de (accessed on 6 February 2021).

58. Durán, C.A.; Córdova, F.M.; Palominos, F. A conceptual model for a cyber-social-technological-cognitive smart medium-size port. Procedia Comput. Sci. 2019, 162, 94-101. [CrossRef]

59. Comisión Estrategia 2030 de Puertos y su Logística. Logística y Puertos: Una Plataforma Estratégica de Desarrollo Para Chile; Technical Report; Consejo Nacional de Innovación para el Desarrollo: Santiago, Chile, 2015.

60. Doerr, O. Gobernanza de la ciudad puerto en América Latina: Diálogo y estrategias colaborativas para un desarrollo sostenible de la infraestructura. Marit. Logist. Bull. 2017, 65, 1-9.

61. Ministerio de Desarrollo Social. Informe de Diagnóstico e Implementación de la Agenda 2030 y los Objetivos de Desarrollo Sostenible en Chile; Technical Report; Ministerio de Relaciones Exteriores: Santiago, Chile, 2017.

62. Frohmann, A.; Mulder, N.; Olmos, X. Incentivos a la Sostenibilidad en el Comercio Internacional; Publicación de las Naciones Unidas: Santiago, Chile, 2020; p. 176.

63. Lim, S.; Pettit, S.; Abouarghoub, W.; Beresford, A. Port sustainability and performance: A systematic literature review. Transp. Res. Part D Transp. Environ. 2019, 72, 47-64. [CrossRef]

64. Schrobback, P.; Meath, C. Corporate sustainability governance: Insight from the Australian and New Zealand port industry. J. Clean. Prod. 2020, 255, 120280. [CrossRef]

65. Hinkka, V.; Eckhardt, J.; Permala, A.; Mantsinen, H. Changing Training Needs of Port Workers Due to Future Trends. Transp. Res. Procedia 2016, 14, 4085-4094. [CrossRef]

66. Chen, J.; Huang, T.; Xie, X.; Lee, P.T.; Hua, C. Constructing Governance Framework of a Green and Smart Port. J. Mar. Sci. Eng. 2019, 7. [CrossRef]

67. Acciaro, M.; Vanelslander, T.; Sys, C.; Ferrari, C.; Roumboutsos, A.; Giuliano, G.; Lam, J.S.L.; Kapros, S. Environmental sustainability in seaports: a framework for successful innovation. Marit. Policy Manag. 2014, 41, 480-500. [CrossRef]

68. Walker, T.R. Green Marine: An environmental program to establish sustainability in marine transportation. Mar. Pollut. Bull. 2016, 105, 199-207. [CrossRef]

69. Rodrigues, V.; Russo, M.; Sorte, S.; Reis, J.; Oliveira, K.; Dionísio, A.L.; Monteiro, A.; Lopes, M. Harmonizing sustainability assessment in seaports: A common framework for reporting environmental performance indicators. Ocean Coast. Manag. 2021, 202, 105514. [CrossRef]

70. Lee, P.T.; Kwon, O.K.; Ruan, X. Sustainability Challenges in Maritime Transport and Logistics Industry and Its Way Ahead. Sustainability 2019, 11, 1331. [CrossRef]

71. Ashrafi, M.; Acciaro, M.; Walker, T.R.; Magnan, G.M.; Adams, M. Corporate sustainability in Canadian and US maritime ports. J. Clean. Prod. 2019, 220, 386-397. [CrossRef]

72. Asgari, N.; Hassani, A.; Jones, D.; Nguye, H.H. Sustainability ranking of the UK major ports: Methodology and case study. Transp. Res. Part E Logist. Transp. Rev. 2015, 78, 19-39. [CrossRef]

73. Di Vaio, A.; Varriale, L. Management Innovation for Environmental Sustainability in Seaports: Managerial Accounting Instruments and Training for Competitive Green Ports beyond the Regulations. Sustainability 2018, 10, 783. [CrossRef]

74. Lee, T.; Yeo, G.T.; Thai, V.V. Environmental efficiency analysis of port cities: Slacks-based measure data envelopment analysis approach. Transp. Policy 2014, 33, 82-88. [CrossRef]

75. Hou, L.; Geerlings, H. Dynamics in sustainable port and hinterland operations: A conceptual framework and simulation of sustainability measures and their effectiveness, based on an application to the Port of Shanghai. J. Clean. Prod. 2016, 135, 449-456. [CrossRef]

76. Antão, P.; Calderón, M.; Puig, M.; Michail, A.; Wooldridge, C.; Darbra, R.M. Identification of Occupational Health, Safety, Security (OHSS) and Environmental Performance Indicators in port areas. Saf. Sci. 2016, 85, 266-275. [CrossRef]

77. Kang, D.; Kim, S. Conceptual Model Development of Sustainability Practices: The Case of Port Operations for Collaboration and Governance. Sustainability 2017, 9, 2333. [CrossRef]

78. Hui, F.K.; Aye, L.; Duffield, C.F. Engaging Employees with Good Sustainability: Key Performance Indicators for Dry Ports. Sustainability 2019, 11, 2967. [CrossRef]

79. Salazar, M.; Lagos, C.; Carrasco, R.; Banguera, L.; Durán, C.; Gutiérrez, S. Environmental problems and use of the Clean Production Agreement for their mitigation. In Proceedings of the 2019 IEEE CHILEAN Conference on Electrical, Electronics Engineering, Information and Communication Technologies (CHILECON), Valparaiso, Chile, 13-27 November 2019; pp. 1-6. [CrossRef] 